\title{
Effect of Rational Emotive Behavior Therapy Counseling with Patronage Technique on the Level of Paranoid Ideation in the Prisoner from Correctional Institution
}

\author{
Farid Junaedi $^{1}$, Fatah Hanurawan ${ }^{2}$, H. Triyono ${ }^{3}$, Arbin Janu Setyowati ${ }^{4}$ \\ ${ }^{1}$ Faculty of Education, Universitas Negeri Malang, \\ Correction Science Polytechnic (Poltekip) Kemenkumham RI Jakarta, Indonesia \\ ${ }^{2}$ Faculty of Psychology, Universitas Negeri Malang, Indonesia \\ ${ }^{3.4}$ Faculty of Education, Universitas Negeri Malang, Indonesia \\ ${ }^{1}$ faridjunaedi88@gmail.com, ${ }^{2}$ Fattah.hanurawan.fppsi@um.ac.id, ${ }^{3}$ triyono.fip@um.ac.id, ${ }^{4}$ arbin.janu.fip@um.ac.id
}

\begin{abstract}
In the Correctional Institution (Lapas), there are problems that have not been resolved, such as the repeated riots that have occurred in prisons in Indonesia, over capacity increasing (source: smslap.ditjenpas.go.id) and the death rate of prisoners due to suicide. One of the causes of this phenomenon is mental health problems. Based on preliminary data collection on 100 new prisoners, it shows that $40 \%$ indicated paranoid disorders. This was experienced because of the fear and trauma felt by the prisoners who had just entered the Penitentiary. The emergence of this paranoid disorder has a negative impact on prisoners and prisons because it can cause suspicion, prejudice, both against fellow prisoners and correctional officers and people around them, which can lead to prison riots. Thus, it is necessary to have countermeasures or treatment that can reduce the level of paranoia felt by inmates. The Rational Emotive Behavior Therapy (REBT) with patronage technique counseling model can be a suitable counseling model considering that this approach is a cognitive behavior that emphasizes the connection with feelings, behavior and thoughts, one of which is obtained through social learning. In this study, the analysis was carried out using quantitative approaches (descriptive and inferential analysis of numbers) and qualitative (thematic descriptions and analysis of text or images). The data analysis technique is comparative analysis. For comparative or experimental research, if only two variables are being compared, then the t-test is more appropriate, taking into account the size of the data and the nature of the relationship between the variables. The statistical hypothesis test uses different test Paired Samples T-test because the sample is paired between pre-test and post-test data. The data collected was processed with the SPSS for Windows application program package. Based on the data, it was found that REBT's Treatment Counseling with patronage technique could significantly reduce the level of paranoid inmates. Based on the interview data obtained, the respondents felt more relieved/calmer and could have a more openminded-realistic mind after REBT counseling was carried out in the orientation admission program. However, in this study there are still many influences that cannot be controlled by the researcher such as adaptability, personal factors, environmental factors (residential blocks and friendship) and family visiting/support factors.
\end{abstract}

\section{Keywords}

Prisoners, Over Capacity, Paranoid Ideation, Patronage Technique, Rational emotive behavior therapy, correctional institution 


\section{Introduction}

Based on the data obtained, the riots that occurred within the Penitentiary from time to time showed an increasing and disturbing tendency. Like the riots that occurred in Denpasar Bali's Kerobokan Prison, Sialang B bending prison riots, and many more (34 riots based on the Correctional Data System / SDP from the Director General of Corrections over the last five years), not to mention the mental health disorders that caused the prisoner to commit suicide suicide, prison cases of Lapas Malang, Prisoners in Lapas Lumajang 2018, Prison prisoners Jambi beginning in 2019 and finally Prisoners in Lapas Sragen (Data from the General Director of Correctional showed 63 figures for the last 7 years deaths due to suicide).

The mental health of prisoners becomes an important thing to pay attention to, because prisoners with a certain sentence period, coupled with the number of lost rights and obligations to become a whole human being. Through the approach of Environmental Load Theory, Behavior Constraints Theory, Adaptation Level Theory and Environment Stress Theory, an analysis is found that over capacity in prisons can make prisoners become prisoners depressed, experiencing obstacles in determining the right behavior, decreased adaptability due to environmental factors that are congested, congested and unhealthy, leading to mental health disorders such as: Paranoid, anxiety / anxiety, obsessive-compulsive disorder, phobia, interpersonal sensitivity (SI), hostility , Automation, Psychotics, and even Depression. Which is caused by an environment that is not conducive due to over capacity. Data shows that the capacity of prisons throughout Indonesia is 130,622 people, now in October 2019 inhabited by 266,117 people, specifically for the Lapas Jambi with a capacity of 218 people per person, now in November 2019 it is inhabited by 1377 people per person.

When a person is convicted undergoing a sentence handed down by the court, then their rights as citizens will be limited. In accordance with Law No.12 of 1995, prisoners are convicts who undergo the crime of missing independence at the Penitentiary (Lapas, formerly called Prison).
Correctional facilities are held in the context of forming prisoners so that they become fully human, aware of mistakes, improve themselves, and do not repeat criminal acts, so that they can be accepted again in a free and responsible society. The loss of freedom, self- esteem, feelings of shame, feelings of sadness, guilt, social and economic sanctions are problems that must be endured by a prisoner (Gussak, 2009).

Data was collected in Lapas Jambi in August 2019 using the Symptom Check List 90 (SCL-90) questionnaire. A widely used questionnaire developed by Leonard R. Derogat is to determine a number of psychological symptoms. Where to be measured are 1) Paranoid, 2) Depression, 3) Anxiety, 4) Obsessive-compulsive disorder, 5) Phobia, 6) Interpersonal Sensitivity (SI), 7) Hostility, 8) Automation, 9) Psychotics. The subject of the study was the new Prisoners / Detainees of Lapas Jambi. Data collection was carried out for 100 Prisoners. With $40 \%$ experiencing paranoid symptoms (40 people).

\section{Results of Data Collection with SCL-90}

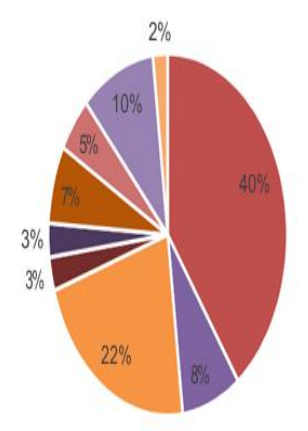

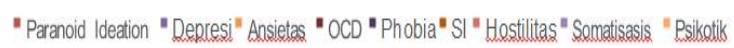

Diagram 1.1. Results of data retrieval with SCL90

Based on the above sampling there were 40 Prisoners who experienced mild paranoid ideation. Although mild, this can be enough to be considered because if it is not resolved, it can develop into paranoid disorders which gradually get higher. Someone who has paranoia thinks irrationally. The fears experienced are a form of irrational thought possessed by him to his environment, so as to minimize the symptoms felt by irrational thoughts that arise must be changed into rational thought. 
The counseling model that focuses on changing irrational thinking into rational thinking is the Rational Emotive Behavior Therapy (REBT) counseling model. REBT can change negative thoughts and maladaptive beliefs possessed by individuals into rational thinking (Corey, 2009). This counseling emphasizes individuals to think, judge, decide, analyze and act. Prisoners change their initial illogical and irrational way of thinking by replacing them with something logical and rational by confronting their irrational beliefs and attacking, opposing, questioning and discussing irrational beliefs so that prisoners will be happy, productive and quality.

This Patronage Counseling Technique becomes a new formula for Lapas Jambi officers to be applied to prisoners. In this counseling technique the emphasized element is the meaning of happiness conveyed to prisoners who have problems as follows:

1. In prisons, prisoners interact by and only with Lapas Employees where the employee is appointed as Correctional Guard who is tasked with nurturing inmates. Therefore, the relationship between the Correctional Institution and prison inmates must be well established. Because this Correctional Guardian who will be the first hand outstretched for inmates.

2. Every human being changes, sometimes overwrites problems that are felt heavy, and sometimes experiences feelings of pleasure. Must be accepted as a blessing from God, the settlement process must be slow and flexible.

3. There is thankfulness and self-evaluation / introspection that is mature by working together (trust by looking at one's abilities /self-reality)

4. The progress of the era that is getting faster and more transparent news making everyone can be easily controlled by news that is not a little misleading.

5. Strong with tests and trials through sufficient mental / religious mentality, sincerity of accepting the destiny that has been attempted (endeavor and trust) and sharing with others and this is part of life must be lived comfortably.

6. There is no need to stay in line with this life. Because that is precisely the potential to form a tense and egocentric person (Be flexible self).

7. Understanding of human capabilities that must have flaws and have made mistakes. Without mistakes we cannot be successful and happy.

8. Socializing and socializing (understanding and understanding the public interest and legislation) requires adequate moral ethics.

9. Keeping our minds to always be in the position of 'conscious', especially in the chaotic conditions of the world like this.

The points of happiness above will be conveyed to every prisoner who has a problem and then combined with the rational emotive behavior therapy counseling model so that positive thinking is formed in dealing with problems both problems that originate from outside the prison (family, relatives, friends) or within prisons.

\section{Theoretical Background}

\section{a. Paranoid Ideation Theory}

According to Darajat (2007), the notion of Paranoia is 'crazy greatness' or 'crazy accusing people'. Among the characteristics of this disease is delusion, which is a false thought that rules the person being attacked. Paranoid personality disorder (PPD) is a characteristic condition where individuals cannot trust and be suspicious of others excessively. Said to be a form of interference if the behavior is permanent, annoying and distressing. However, this behavior is not referred to as a form of personality disorder if the appearance of the behavior is caused by schizophrenia, mood disorders (such as major depression) with psychotic symptoms, or other psychotic disorders (neurological factors), or causes caused by medical conditions.

According to Darajat (2007) this delusion differs according to the atmosphere and personality of the sufferer, for example:

- The sufferer has a wrong opinion (belief), all his attention is directed there and that one is also the fruit of his speech, so that everyone he meets will be convinced of the truth of his opinion. For example, there was a prisoner who thought that his roommate intended to poison him while eating. So always avoid eating together, for fear of being exposed to the poison.

- The sufferer feels that there are people around him (in prison) and always try to drop it or it will abuseit. 
- The sufferer feels that he is a great person, great, has no equal, believes he is a great leader or may claim to be leader and underestimate the surroundings (for the case of a former official who entered prison).

Delusions or wrong thoughts that are felt by sufferers are very dominating and cannot be lost. Except that the way his mind looks orderly and steady. At the beginning people think that their thoughts are logical and correct. According to Darajat (2007) usually a person who is attacked by paranoia is intelligent, his memory is strong, and his emotions look balanced and match his thoughts. It's just that he has a wrong belief, so that his attention and words are always controlled by his wrong thoughts.

In Wiramihardja (2010) psychoanalytic theorists argue that paranoid personality disorder is the result of the needs of people who reject true feelings and project those feelings into others. Diagnostic Criteria for Paranoid Personality Disorders in DSM IV-TR, namely:

1. Pervasive distrust and suspicion to others so that their motives are considered to be malicious, beginning in early adulthood and appearing in the following context:

- Suspecting without sufficient grounds, that other people use, harm or betray themselves (suspicion because in prison people have problems / enemies in the community gather).

- Preoccupation with improper doubts about loyalty or honesty of friends or coworkers. (considers all prison inmates to be criminals and not to bet rusted)

- Reluctant to tell other people's secrets because of unnecessary fear that information will be used maliciously against him.

- Reading the meaning of condescending or threatening that is hidden from ordinary speech or events.

- Persistently bear a grudge that is not forgiving loss, injury or neglect. (assume that all prisoners are real enemies)

- Feel an attack on his character or reputation that is not visible to others and quickly react angrily or retaliate.

- Have repeated suspicions, without consideration, about loyalty or sexual partners. (mudahberprasangkakarenamenganggapbahwase muawbpadalah orangjahat)
2. Does not occur solely during the course of schizophrenia, a mood disorder with psychotic characteristics, or other psychotic disorders and not because of the immediate physiological effects of a general medical condition.

According to Dwiputri (2013), people with paranoid personality disorders rarely seek treatment, most likely because of their suspicion of others, including psychiatrists and therapists. Individuals with paranoid personality disorder are very afraid of allowing others to see their vulnerabilities and other weaknesses. The first important step is to get the trust of the client. In addition to diagnosing and managing client's main complaints, therapists must be careful to support and listen patiently, to their accusations and complaints while being open, honest and respectful.

Psychoanalytic theorists argue that Paranoid Personality Disorder (PPD) is the result of the need for people to reject their true feelings and project those feelings into others. Then cognitive theorists see PPD as the result of a fundamental belief that others as people who are jealous and deceptive, combined with a lack of confidence in defending themselves against others (Wiramihardja, 2005). Individuals with paranoid personality disorder find it hard to believe and suspect excessively when interacting with others, so PPD individuals feel afraid to be close to anyone; suspecting a stranger even if that person isn't right to be suspected. PPD individuals have few friends, it is difficult to trust others, making this individual unable to be invited to work together in a team. However, that does not mean that paranoid personality disorder cannot be married. Jealousy and the desire to control their partners become part of pathology in their relationships with their partners.

\section{b. Rational Emotive Behavior Therapy Theory}

REBT is a cognitive behavioral approach that emphasizes the relationship between feelings, behavior and thoughts (Komalasari, 2014). Human tendency to think rationally and irrational is one of human nature. REBT is also a 'directive approach', that is, an approach that re-teaches the counselee to understand cognitive input that causes emotional disturbances, tries to change the 
counselee's mind to let his emotional thoughts or learn to anticipate the benefits or consequences of behavior. This also happened to prisoners who were in prison (do not accept their presence in prison). Prisoners also have a tendency to have irrational thoughts, which can then influence the behavior of prisoners who are in prison. REBT as a counseling model is expected to change irrational thinking that can influence prisoners' emotions and behavior.

The ABC model is the core of REB counseling practices and therefore its implementation must get more detailed attention (Dryden \& Neenan, 2004: 7). A represents an activating event. There are two types of A (activating events) in REB counseling, the first is 'A situational' which refers to the objective aspects of the situation that disturb the individual. The second A is 'A critical' which refers to the subjective aspect of the situation that bothers the individual. In general, 'A critical' is an inference of what happens to 'A situational'. B represents Beliefs or beliefs. Beliefs are evaluative cognitions or structured views of things around individuals, which can be either rigid or flexible, extreme or non- extreme. When individual beliefs are rigid, they are called 'irrational beliefs' and are usually in the form of necessity, absolutes, or obligations towards something. Individuals who have rigid beliefs will tend to make irrational conclusions. $\mathrm{C}$ represents Consequence, is an emotional, thought and behavioral consequence that arises from a belief (belief) on a triggering situation (A). In REB counseling, $\mathrm{C}$ that follows irrational beliefs about negative A's will be disruptive and is called negative unhealthy consequences. Conversely, $\mathrm{C}$ that follows rational beliefs about negative $\mathrm{A}$ is non-intrusive and is called healthy negative consequences (Ellis, 1994; in Dryden \& Neenan, 2004).

According to Setiani (2017) in her research journal entitled Group Guidance with ABCDE Formula Teaching Rational Emotive Behavior Approach to Improve Student's Self Efficacy Prospective Teachers explain, that:

REBT is this approach that helps change the irrational beliefs that cause problems with rational beliefs by giving counselees an explanation, understanding and understanding of
$A B C D E$ concepts or formulas so that counselees will eventually be able to overcome their own problems with the understanding they already have. In the rational emotive behavior counseling step there are basic and initial steps that must be understood by the counselee namely the explanation and teaching of the ABCDE formula. If the $A B C D E$ formula has been understood by the counselee then the steps to individual / group counseling services will be easy to do and it is hoped that the counselee can overcome his own problems with the understanding he has received.

Ellis elaborates on his theory by suggesting that a complex of thoughts and emotions tends to become more and more disturbed when it is specifically based on a musturbatory belief system that consists of absolute necessity (for example "I really have to be liked by everyone"). Therefore, recognizing and controlling the absolute necessity of a musturbatory belief system is likely to reduce emotional disturbances. Regardless, Ellis strongly believes that each individual must assume responsibility for his behavior. The REBT phases through Patronage counseling can be stated in the guidelines submitted by Dryden and Neenan (2006), namely the Beginning Stage, the Middle Stage and the Ending Stage. The three stages include 10 sub-stages, namely:

a. Beginning Stage

1) Building work alliances

2) Teach the ABC model to the counselee

b. Middle Stage

1) Overcoming counselee doubts

2) Consider changing the focus of the problem

3) Identify and modify core irrational beliefs

4) Encourage the counselee to get involved in relevant tasks

5) Help the counselee to internalize new rational beliefs by using imagery techniques in patronage REB therapy. (advising, enlightenment, protecting and rectifying ways of thinking related to the meaning of happiness)

6) Overcoming obstacles to change.

7) Encourage the counselee to maintain and improve what has been achieved.

8) Encourage the counselee to become a counselor for himself

c. Ending Stage 
In this final stage the counselor is allowed to reward the counselee for his active role in attending counseling intervention sessions, as well as offering individual counseling services.

There are things that distinguish prisoner counseling from counseling in general. Where, the position between the client and counselor is not equal. This is because prison officers with inmates have unequal relations. Where correctional officers are guardians / supervisors / guiding prisoners while in prison (have a functional structure or organizational structure). Surely it will lead to inequality in prison relations with officers, so that counseling techniques that are carried out in general cannot be applied in this condition. Therefore the authors propose a Patronage Counseling Technique, a counseling technique adopted from Patron-Client theory (Scott, 1994) which explains, that the relationship between the role of Patron and Client is a special relationship in the form of instrumental friendship in which the Patron has power, status, and higher authority than the Client, such as the relationship between the supervisor in prisoners and prison in the context of the duties, responsibilities and obligations of each party. Interaction between supervisor and prisoners such as Patron-Client relationship which is realized for counseling purposes. Thus the authors call it the Patronage Counseling Technique.

\section{Method}

The method used in this study is mixed methods, which combines quantitative methods and qualitative methods. This study uses quantitative methods as the main research method (primary) and qualitative research methods as a support. This strategy is a concurrent embedded strategy, which is a strategy in mix methods that applies one stage of quantitative and qualitative data collection at a time, has a primary method (the main method that guides and is more dominant used in research) and a secondary method (which plays a supporting role). Quantitative research methods are used to determine the effectiveness of counseling with the REBT approach and patronage techniques, while the qualitative method is used in the preliminary study stage and explores the intervention process that is applied / implemented to see its effects on paranoid ideation. In the primary method of this research, namely quantitative, the design used is Quasi Experiment Design which in its implementation does not use random assignments (random assignment), but instead uses a group that has been formed (intact group). This is in accordance with Creswell's statement (2012) that: "Quasiexperiments include assignments, but not random assignments of participants to groups".

The quasi experimental design used was Nonequivalent Pretest-Posttest Control Group Design. In the secondary method of this research, namely qualitative, data collection uses guidelines for field observations, interviews, prisoners during the pretest assessment process, and documentation/records to explore the process of the intervention. This research was conducted in Lapas Jambi, with the population of the study was the Prisoners of Prison Lapas Jambi, a number of 1363.

Sampling uses a purposive sampling technique, namely the method of selecting samples by selecting certain samples that are assessed according to the objectives or research problems in a population (Nursalam, 2008). First of all the prisoners was conducted a pretest to see the level of paranoid ideation using the SCL-90 measuring instrument. Of the 100 prisoners that were sampled for pretesting, 40 respondents were indicated to be paranoid which were then used as research samples. Data collection methods used in this study is primary data collection methods, namely quantitative data and secondary data collection methods, namely qualitative data. Quantitative data were obtained using the Symptoms Checklist 90 (SCL-90). Symptom Check List 90 (SCL-90-R) is a widely used questionnaire developed by Leonard R. Derogat is to determine a number of psychological symptoms. Where to be measured are 1) Paranoid, 2) Depression, 3) Anxiety, 4) Obsessivecompulsive disorder, 5) Phobia, 6) Interpersonal Sensitivity (SI), 7) Hostility, 8) Automation, 9) Psychotics. Symptoms Check List 90 (SCL-90) is a psychometric instrument developed from the Hopkins Symptoms Check List, in the form of a self-rating questionnaire, consisting of 90 questions. There is a mental disorder if the total score of SCL-90 is more or equal to 61, there is no 
mental disturbance if the total score of SCL-90 is less than 61 . The tendency of the dominant mental disorder symptoms experienced by respondents can also be assessed by grouping questions based on the type of psychopathological symptoms, as follows with the reliability and validity values obtained from the research journal Validity assessment of the symptom checklist SCL-90-R and shortened versions for the general population in Ukraine by Yuliia Sereda and Serhii Dembitskyi (2016):

- Paranoid Questions included in the paranoid scale are 8, 18, 43, 68, 76 and 83. (Reliability:0.84)

- Depression. Questions included on the depression scale are no. 5, 14, 15, 20, 22, 29, 30, 31, 32, 54, 71 and 79. (Reliability:0.91)

- Anxiety. Questions included on the anxiety scale are no. 2, 17, 23, 33, 39, 57, 72, 78, 80 and 86. (Reliability:0.92)

- Obsessive-compulsive disorder. Questions included in the obsessive compulsive scale are no. $3,9,10,28,38,45,46,51,55$ and 65 . (Reliability:0.90)

- Phobias. Questions included in the phobia scale are no. 13, 25, 47, 50, 70, 75 and 85 . (Reliability:0.87)

- Interpersonal sensitivity (SI). Questions included on the interpersonal sensitivity scale are 6, 21, 34, 36, 37, 41, 61, 69 and 73. (Reliability:0.87)

- Hostility. Questions included in the hostility scale are 11, 24, 63, 67, 74 and 81. (Reliability:0.82)

- Automation. Questions included in the automation scale are 1, 4, 12, 27, 40, 42, 48, 49, 52, 53, 56 and 58. (Reliability:0.93)

- Psychotic. Questions included in the psychotic scale are 7, 16, 35, 62, 77, 84, 85, 87, 88 and 90. (Reliability:0.90)

Based on the results of validation tests in Indonesia conducted by Herianto (1994) with a balanced sensitivity and specificity approaching $100 \%$, namely $82.92 \%$ and $83 \%$ with positive predictive values $80 \%$ and negative predictions $84.69 \%$. This questionnaire measures the mental emotional state of someone who in this study is a prisoner in quantitative terms. Respondents answered this question by giving a value for each question on a scale of 0 to 4 selected according to the symptoms they experienced in the past 1 month. Then for qualitative data obtained using field observation guidelines and interview guidelines. In this study the analysis was carried out based on a quantitative approach (descriptive and inferential analysis of figures) and qualitative (thematic description and analysis of texts or images). The data analysis technique is comparative analysis with $\mathrm{t}$ test. According to Setiani (2017) for comparative or experimental research, if only two variables are compared, the more appropriate use is the t-test by considering the size of the data and the nature of the variable relationship. To test the null hypothesis the t test is used through the Paired Samples t-test, because the sample is paired between pre-test and post-test data. The collected data is processed with the SPSS for Windows application program package. In addition to being quantitative, the analysis was also carried out with qualitative, namely thematic description and analysis of text or images (there is an explanation to find out the progress of the counselee every time treatment is done). The hypothesis proposed in this study is:

H1: The average paranoid level of new prisoners before and after REBT counseling is given patronage techniques are different.

H0: The average level of new paranoid prisoners before and after being given REBT counseling is the same patronage technique.

\section{Result and Discussion}

\section{Result}

Table 1. Average New Paranoid Prisoners Levels Before and after being given REBT counseling

$$
\text { Average N Standard Deviation Standard Error }
$$

Mean

\begin{tabular}{llllll}
\hline Pair1 & BeforeTes & 1,7750 & 40 & 0,73336 & 0,11595 \\
& After Tes & 0,5750 & 40 & 0,63599 & 0,10056 \\
\hline
\end{tabular}


Table 1 above shows that the average level of new paranoid Prisoners before and after patronage technique REBT counseling was given. Before being given REBT counseling the patronage technique the average paranoid level of 40 subjects was 1,775 whereas after being given REBT counseling the patronage technique the average paranoid level of 40 subjects was 0.575 . This means that there is a reduction of 1,200.

Based on these results, it can be concluded that there is a decrease in the level of paranoid inmates after getting REBT counseling therapy. Then when viewed from its significance then as attached in the table below:

The table above shows the $\mathrm{t}$ value is 14,697 with sig $(p)=0,000$. Because sig $<0.05$, it can be concluded that $\mathrm{H} 1$ is accepted, meaning that the average level of new paranoid Prisoners before and after being given REBT counseling patronage technique is significantly different. Thus it can be stated that providing REBT counseling with patronage techniques can reduce the level of paranoid new Prisoners.

Table 2. Decrease in paranoid levels of inmates after REBT therapy

\begin{tabular}{|c|c|c|c|c|c|c|c|c|c|}
\hline & & \multirow{2}{*}{$\begin{array}{l}\text { Rata- } \\
\text { Rata }\end{array}$} & \multirow{2}{*}{$\begin{array}{l}\text { Standar } \\
\text { d } \\
\text { Deviasi }\end{array}$} & \multirow{2}{*}{$\begin{array}{l}\text { Standard } \\
\text { Error } \\
\text { Rata-Rata }\end{array}$} & \multicolumn{2}{|c|}{$\begin{array}{c}\text { 95\% Confidence } \\
\text { Interval of the } \\
\text { Difference }\end{array}$} & \multirow[t]{2}{*}{$\mathbf{t}$} & \multirow[t]{2}{*}{ df } & \multirow{2}{*}{$\begin{array}{l}\text { Sig. (2 } \\
\text { Arah) }\end{array}$} \\
\hline & & & & & Terenda h & Tertinggi & & & \\
\hline $\begin{array}{l}\text { Pasangan } \\
1\end{array}$ & $\begin{array}{l}\text { SebelumTes } \\
\text { - SesudahTes }\end{array}$ & 1,2000 & 0,51640 & 0,08165 & 1,03485 & 1,36515 & 14,697 & 39 & 0,000 \\
\hline
\end{tabular}

Based on the results of statistical calculations obtained, that the research hypothesis is accepted that there are significant differences in the level of paranoid before and after getting REBT counseling treatment. Based on the data also found, that the average level of paranoid decreased after getting REBT counseling, so it can be said that REBT counseling can reduce the paranoid level of Lapas Jambi. This quantitative data is also supported by qualitative data obtained from respondents. A respondent (AD) said that "after doing counseling, the feeling felt more relieved than before". Respondents (DE) also conveyed the same thing, namely "After conducting counseling, tend to be able to see the problem from the other side". This was also expressed by respondents (RT), "after doing counseling, felt more inclined to accept what was experienced by him".

The opinions expressed by some of the respondents above show that REBT counseling has a positive effect on him and tends to change the way of thinking before. In the research journal Setiani (2017) explains the REBT theory delivered by Albert Ellis where there are five steps referred to as A-B-C-D-E. "A" includes experiences such as family difficulties, work constraints, childhood trauma, and other things that cause unhappiness. In this study, "A" as an activating for prisoners is quite varied but most of them are more directed to the fear that is in him to a figure who is more authority. This can occur due to past experiences experienced by prisoners when there are arrests, raids, interrogations, thus causing him to have suspicions on people who have more authority/authority over him. Furthermore "B" includes beliefs that are especially irrational and self-destructive which are also a source of unhappiness. In this study, when seeing the figure of officers or people with higher authority than inmates (police, prosecutors, etc.) causes prisoners to think that they will be trapped, arrested, blamed, punished, so that there arises a feeling of lack of trust in others, followed by prejudice bad so it causes anticipatory attitudes of inmates. "C" is the consequence of neurotic symptoms and negative emotions such as panic, resentment, and anger due to depression that comes from false beliefs. When you see someone who has high authority, the feelings that accompany based on data are hatred, revenge, anger, not wanting to deal, avoidance and so on. Then, for " $\mathrm{D}$ ", which is an irrational belief that must be resisted by a therapist so that his client can think rationally. This is done by the therapist such as directing the 
meaning of happiness, advising to do good, giving the understanding that not all people who have more authority than him as inmates give bad behavior towards him. This is reinforced by the sympathy and empathy shown by prison employees to prisoners. However, this does not reduce the firm feeling and discipline possessed by prison officers. Over time, inmates feel that what is delivered by the therapist is a right thing which then convicts believe in it and make ("E") the positive psychological side of rational beliefs.

\section{Conclusion}

In this study, mental health disorders of paranoid ideation with a mild level can be minimized with the counseling model Rational Emotive Behavior Therapy (REBT). This counseling model emphasizes the relationship between feelings, behavior and thoughts, so that inmates can slowly change the way of thinking that was originally illogical and irrational by changing it to something logical and rational. Because prisoner counseling is different from counseling in general, REBT is carried out using patronage counseling technique. In this study, of course, it is not immune to outside influences outside the treatment given. Factors that may affect, include: Personal factors, where different experiences experienced by each person can affect the results of this treatment/counseling. Environmental factors where each prisoner has a residential block that can be different so that his friends are also different. The visiting factor, where the prisoner has a different number of visits or visits that can affect the prisoner's psychology through sympathy, support, love from family. However, in this study there are still many influences that the researcher cannot control, such as adaptability, personal factors, environmental factors (residential blocks and friendship) and family support factors.

\section{References}
[1] American Psychiatric Association, Diagnostic Criteria from DSM-IV, American Psychiatric Association; Washington DC; 1994.

[2] Clark, L.A., Watson, D. \& Mineka, S. 1994. Temperament, personality, and the mood and anxiety disorders. Journal of Abnormal
Psychology, 103, 103-116.

[3] Cloninger, C. R. 1986. A unified biosocial theory of personality and its role in the development of anxiety states. Psychiatric Developments, 4,167-226.

[4] Corey, Gerald. 2009. Teori dan Praktek Konseling dan Psikoterapi. Bandung: Rafika Aditama.

[5] Creswell, J., W., 2012, Research design Pendeka tankualitatif, Kuantitatifdan Mixed; Cetakan ke-2, Yogyakarta: Pustaka Pelajar.

[6] Dahlan, M.Y.Al-Barry, 2003. Kamus Induk Istilah Ilmiah Seri Intelectual Surabaya. Target Press. Hlm 53.

[7] Daradjat, Zakiah. 2007. Kesehatan Mental. Jakarta: PTGunung Agung. Cet. Ketujuh.

[8] Derogatis LR. SCL-90-R: Administration, Scoring of Procedures Manual-II for the R (evised) Version and Other Instruments of the Psychopathology Rating Scale Series: Clinical Psychometric Research Incorporated. 1992.

[9] Dryden, Windy \& Neenan, Michael. (2004). Rational Emotive Behaviour Counselling in Action. 3 rd ed. London: Sage Publication.

[10] Dryden, W. (2006). First Steps in REBT. A Guide to Practicing REBT in Peer Counseling. Albert Ellis Institute. NewYork.

[11] Dryden, W. \& Neenan, M. 2006. Rational Emotive Behaviour Therapy: 100Key Points and Techniques. London: Routledge.

[12] Dwiputri, V. 2013. Gangguan Kepribadian Paranoid.

https://www.kompasiana.com/vinadwiputr i/552b336ff17e61627ed623b4/gangguankepribadian-paranoid (7 November 2019)

[13] Gussak, D. 2009. The Artsin Psychotheraphy Comparing the Effectiveness of arttheraphy on depression and locus of control of female and male inmates. The Arts in Psychotheraphy, 36, 202-207.

[14] Herianto M.1994. Penentuan T. Score Standart Normal Instrumen PsikometrikSCL90 dan UjiCoba. Tesis. 
Fakultas Kedokteran Universitas Indonesia Departemen Psikiatri : Jakarta

[15] Komalasari, G. 2014. Teori dan Teknik Konseling. Jakarta: Indek

[16] Nursalam, 2008. Konsep dan Penerapan Metodologi Penelitian Ilmu Keperawatan.

[17] Jakarta:.Salemba Medika

[18] Republik Indonesia. 1995. Undang-Undang No.12 Tahun1995 Tentang Pemasyarakatan.

[19] Kementerian Hukumdan HAM Republik Indonesia.

[20] Republik Indonesia. 1981. Undang-Undang Nomor 8 Tahun 1981.

[21] Sarracino, D., Dimaggio, G., Ibrahim, R., Popolo, R., Sassaroli, S., Ruggiero, G.M. (2017). When REBT Goes Difficult: Applying ABC-DEF to Personality Disorders. Journal of Rational-Emotive and Cognitive-Behavior Therapy, 35(3), 278-295. doi:10.1007/s10942-016-0258-7

[22] Scott, J.C. 1994. Moral Ekonomi Petani. Jakarta: LP3ES.

[23] Setiani, I.B., Taufiq, A., Suherman, S. 2017. Bimbingan Kelompokdengan Pengajaran Formula ABCDE Pendekatan Rasional Emotif Behavioruntuk Meningkatkan Self Efficacy Mahasiswa Calon Guru. Jurnal Kajian Bimbingan dan Konseling, 2(1), 2017, 9-17. Diaksesdi http://journal2.um.ac.id/index.php/jkbk

[24] Tyszkowska, M., \& Podogrodzka, M. (2013). Stigmatization on the way to recovery in mental illness- The factors directly linked to psychiatric therapy. Psychiatria Polska,47(6), 1011-1021.

[25] Wiramihardja, Sutardjo. (2005). Pengantar Psikologi Abnormal. Bandung: Refika Aditama.

[26] Wiramihardja, Prof. Dr. Sutardjo A., psi. 2010. Pengantar Psikologi Abnormal. Bandung: PT. Refika Aditama 